\title{
EVALUATING THE EFFECTS OF DRIP DEFICIT IRRIGATION AND THICKNESS OF RICE STRAW MULCH LAYER ON BEANS CROP AND WATER USE EFFICIENCY
}

\author{
Abd El-Wahed, M. H. ${ }^{1}$, Baker, G. A. ${ }^{2}$, Ali, M. M. ${ }^{1}$ and \\ Abd El- Fattah, Fatma A. ${ }^{1}$
}

\begin{abstract}
Two field experiments were conducted during the two growing seasons (2014 and 2015) to investigate the combined effects of three irrigation treatments $\left(I_{100 \%}=100 \%, I_{85 \%}=85 \%\right.$ and $I_{70 \%}=70 \%$ of crop evapotranspiration (ETc)and four thicknesses of mulch layer $\left(T M L_{0}, 3,6\right.$ and ${ }_{9} \mathrm{~cm}$ ) under drip irrigation system.

The Results showed that the irrigation treatments and thickness of mulch layer on yield and WUE were significant.

The greatest values of bean yield (902.4and $909.6 \mathrm{~kg} \mathrm{fed}^{-1}$ ) were obtained under $\left(I_{100 \%}\right)$ in the first and second seasons, respectively, while the lowest ones (698.1 and $\left.692.5 \mathrm{kgfed}^{-1}\right)$ were obtained from treatment $\left(I_{70 \%}\right)$ in the first and second seasons, respectively. The average bean yield value of $T M L_{9}$ was increased by 11.5, 30.8 and $40.2 \%$ than those of treatment $T M L_{6,3}$ and 0 , respectively, in the first season. Corresponding values for the second season were 12.3, 32.5 and $43.5 \%$ The greatest values of WUE $\left(0.74\right.$ and $\left.0.73 \mathrm{~kg} \mathrm{~m}^{-3}\right)$ were obtained under $I_{70 \%}$ compared to $I_{100 \%},\left(0.67 \mathrm{~kg} \mathrm{~m}^{-3}\right)$ in the two seasons, respectively.

The interacting effects between treatment $\mathrm{I}_{100}$ and treatment $T M L_{9}$ i.e. $\left(I_{100} \times T M L_{9}\right)$ has proved, to be the most suitable for producing high bean crop. Under environmental condition of the studied area. Application of $\left(I_{85} \times T M L_{9}\right)$ treatment was found to be favorable to save $15 \%$ of the applied irrigation water, with no decrease in bean crop yield.
\end{abstract}

Key word: Drip irrigation, deficit irrigation, thickness of mulch layer, WUE, beans crop.

1- Agricultural Engineering Department, Faculty of Agriculture, Fayoum University.

2- Agricultural Engineering Department, Faculty of Agriculture, Cairo University. 


\section{INTRODUCTION}

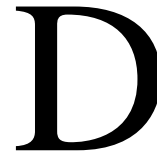
ry bean (Phaseolus vulgaris L.) is a human food high in protein, phosphorus, zinc, iron, vitamin B1, and fiber. It is the most important legume worldwide for human consumption because it is a good source of protein (Ramirez Builes et al., 2011). According to Food and Agriculture Organization (FAO) Statistics (2013), dry bean is globally cultivated in 29,290,861 ha and produced 23,598,102 tones with an average of 0.806 tones $\mathrm{ha}^{-1}$ (o.336 ton $\mathrm{fed}^{-1}$ ). In Egypt, the total area devoted for the production of dry bean yield was 63,710.4 fed and produced 69,486 tones with an average of 1.09 tones fed ${ }^{-1}$.

The declining availability of fresh water has become a worldwide problem, especially in arid and semi-arid regions where irrigation is necessary for crop production (Wei et al., 2016). More than $80 \%$ of water resources have been exploited for agricultural irrigation in Egypt (Egypt in Figures, 2015). Therefore, it is necessary to develop strategies to optimize the efficiency of water use, while maintaining the quantity and quality of the production (Nangare et al., 2016).

Water use efficiency and yield of crops can be improved by using drip irrigation under limited water applications by decreasing the amount of water that leaches out of the root zone (El-Hendawy et al. 2008).Deficit irrigation (DI) aims to increase water use efficiency (WUE) by eliminating irrigation events that have little impact on yield. However, this application can also have other benefits related with decreasing nitrate leaching, reducing the energy used during irrigations (since most irrigation equipment is pressurized), maximizing the competitiveness of the agricultural sector (Falagánet al., 2015),reducing production costs and water consumption (Pulupolet al., 1996). Combine practice of DI and soil mulching appears to be very promising among the water management practices for increasing WUE especially at field scale. The main advantages associated with mulching are less water losses through evaporation from soil surface, there for less water required for irrigation, (Trenoret al., 1998), (ii) advance of harvest (FerrerTalón et al., 2004), and (iii) the bigger size of plants (Melgarejoet al., 1998). Cover crop mulch that remains on the soil surface can be used to add soil organic matter (Dabneyet al., 2001). Mulching is an efficient way to reduce evaporation, 
improve WUE (Hartkampet al., 2004) and maintain soil under stable temperature (Karand Kumar, 2007). Few studies have examined the combined effects of irrigation water applied and thickness of mulch layer on plant grain yield and water use efficiency.

The present investigation was planned to determine the effects of deficit irrigation and thickness of mulch layer on common bean yield, yield components and water use efficiency under drip irrigation system.

\section{MATERIALS AND METHODS}

\subsection{Experimental field}

Two field experiments were conducted during the two growing seasons (2014 and 2015) at the private Farm; Ansar graduates village Ihnasiya Sdment mountain Center, Beni Suef, Egypt. Objective of this work was mainly to determine the effects of drip deficit irrigation and thickness of mulch layer on common bean yield, yield components and water use efficiency. Physical and chemical properties of the experimental soil are given in tables (1 and 2).

Table (1): Physical properties of the experimental soil.

\begin{tabular}{|c|c|c|c|c|c|c|c|c|}
\hline \multirow{3}{*}{$\begin{array}{l}\text { Soil } \\
\text { depth, } \\
\mathrm{cm}\end{array}$} & \multicolumn{4}{|c|}{ Particle size distribution } & \multirow{3}{*}{$\begin{array}{c}\text { Bulk } \\
\text { density } \\
(\mathrm{Pd}) \\
\mathrm{Mg} \mathrm{m}^{-3}\end{array}$} & \multirow{2}{*}{$\begin{array}{c}\text { F.C } \\
\% \\
\text { on }\end{array}$} & \multirow{2}{*}{$\begin{array}{c}\text { W.P } \\
\%\end{array}$} & \multirow{2}{*}{$\begin{array}{c}\text { A.W } \\
\%\end{array}$} \\
\hline & \multirow{2}{*}{$\begin{array}{c}\text { Sand, } \\
\%\end{array}$} & \multirow{2}{*}{$\begin{array}{l}\text { Silt, } \\
\%\end{array}$} & \multirow{2}{*}{$\begin{array}{c}\text { Clay, } \\
\%\end{array}$} & \multirow{2}{*}{$\begin{array}{c}\text { Texture } \\
\text { class }\end{array}$} & & & & \\
\hline & & & & & & \multicolumn{3}{|c|}{ On weight basis } \\
\hline $0-10$ & 47.2 & 15.3 & 37.5 & S C & 1.46 & 19.79 & 4.69 & 15.10 \\
\hline $10-20$ & 46.3 & 16.8 & 36.9 & $\mathrm{~S} \mathrm{C}$ & 1.57 & 19.42 & 4.64 & 14.78 \\
\hline $20-30$ & 46.9 & 17.1 & 36.0 & $\mathrm{~S} \mathrm{C}$ & 1.58 & 18.62 & 4.37 & 14.25 \\
\hline
\end{tabular}

SC: Sandy clay, FC: Field Capacity, WP: Wilting Point and AW: Available water. (Pd): Bulk density

Table (2): Chemical properties of the experimental soil.

\begin{tabular}{|c|c|c|c|c|c|c|c|c|c|c|}
\hline \multirow{2}{*}{$\begin{array}{c}\text { Depth } \\
\mathrm{cm}\end{array}$} & \multicolumn{4}{|c|}{ Cations $\left(\mathrm{mmol} / \mathrm{dm}^{\mathrm{a}}\right)$} & \multicolumn{4}{|c|}{ Anions $\left(\mathrm{mmol} / d m^{\mathrm{a}}\right)$} & \multirow{2}{*}{$\begin{array}{c}\mathrm{EC}^{\mathrm{a}} \\
\mathrm{dS} \\
\mathrm{m}^{-1}\end{array}$} & \multirow{2}{*}{$\mathrm{pH}$} \\
\hline & $\mathrm{CO}_{3}^{--}$ & $\mathrm{HCO}_{3}^{-}$ & $\mathrm{Cl}^{-}$ & $\mathrm{SO}_{4}^{--}$ & $\mathrm{Ca}^{++}$ & $\mathrm{Mg}^{++}$ & $\mathrm{Na}^{+}$ & $\mathrm{K}^{+}$ & & \\
\hline $0-10$ & 0.00 & 4.20 & 35.0 & 18.20 & 18.20 & 14.53 & 23.25 & 1.42 & 5.74 & 7.40 \\
\hline $10-20$ & 0.00 & 3.89 & 33.4 & 19.21 & 19.21 & 14.65 & 21.30 & 1.34 & 5.65 & 7.38 \\
\hline $20-30$ & 0.00 & 3.55 & 29.8 & 16.85 & 17.32 & 11.76 & 19.84 & 1.28 & 5.02 & 7.52 \\
\hline
\end{tabular}

$\mathrm{EC}^{\mathrm{a}}$ is the average electrical conductivity 


\subsection{Experimental design and treatments}

The experimental layout was a split-plot system in a randomized complete blocks design with three replications. The irrigation treatments were distributed in the main plots, while thicknesses of mulch layer were allocated in sub-plots.

\subsubsection{Irrigation treatments:}

Three irrigation treatments were applied as a percentage of the crop evapotranspiration (ETc) representing one of the following: $\mathrm{I}_{100 \%}=100 \%$ of ETc, $\mathrm{I}_{85 \%}=85 \%$ of ETc and $\mathrm{I}_{70 \%}=70 \%$ of ETc.

\subsubsection{Thickness of mulch layer (TLM):}

Four thicknesses of mulch layer of rice straw mulch $(0,3,6$ and $9 \mathrm{~cm})$ were used. The mulching material was spread manually on the soil surface after sowing. Table (3) gives further description of the experimental treatments.

Table (3): Description of the experimental treatments.

\begin{tabular}{|c|c|l|}
\hline Treatment no. & Treatment label & \multicolumn{1}{c|}{ Description } \\
\hline 1 & $\mathrm{I}_{100 \%} * * \mathrm{RSM}_{0}$ & * IWA 100\% of ETc, no mulch. \\
\hline 2 & $\mathrm{I}_{100 \%} \mathrm{RSM}_{3}$ & IWA 100\% of ETc, RSM with ***TLM $3 \mathrm{~cm}$ \\
\hline 3 & $\mathrm{I}_{100 \%} \mathrm{RSM}_{6}$ & IWA 100\% of ETc, RSM with TLM $6 \mathrm{~cm}$. \\
\hline 4 & $\mathrm{I}_{100 \%} \mathrm{RSM}_{9}$ & IWA 100\% of ETc, RSM with TLM $9 \mathrm{~cm}$. \\
\hline 5 & $\mathrm{I}_{85 \%} \mathrm{RSM}_{0}$ & IWA $85 \%$ of ETc, no mulch. \\
\hline 6 & $\mathrm{I}_{85 \%} \mathrm{RSM}_{3}$ & IWA $85 \%$ of ETc, RSM with TLM $3 \mathrm{~cm}$. \\
\hline 7 & $\mathrm{I}_{85 \%} \mathrm{RSM}_{6}$ & IWA $85 \%$ of ETc, RSM with TLM $6 \mathrm{~cm}$. \\
\hline 8 & $\mathrm{I}_{85 \%} \mathrm{RSM}_{9}$ & IWA 85\% of ETc, RSM with TLM $9 \mathrm{~cm}$. \\
\hline 9 & $\mathrm{I}_{70 \%} \mathrm{RSM}_{0}$ & IWA 70\% of ETc, no mulch. \\
\hline 10 & $\mathrm{I}_{70 \%} \mathrm{RSM}_{3}$ & IWA 70\% of ETc, RSM with TLM $3 \mathrm{~cm}$. \\
\hline 11 & $\mathrm{I}_{70 \%} \mathrm{RSM}_{6}$ & IWA 70\% of ETc, RSM with TLM $6 \mathrm{~cm}$. \\
\hline 12 & $\mathrm{I}_{70 \%} \mathrm{RSM}_{9}$ & IWA 70\% of ETc, RSM with TLM $9 \mathrm{~cm}$. \\
\hline
\end{tabular}

*IWA: Irrigation water applied, **RSM: Rice straw mulch, ***TLM: thickness layer mulch. 


\subsection{Irrigation water applied (IWA)}

Bean plants were irrigated at three days intervals by different amounts of irrigation water.

The daily ETo was computed using equation (1) according to Doorenbosand Pruitt (1992):

$$
\text { ETo }=\text { Kpan } \times \text { Epan }
$$

Where:

Epan = evaporation from Class A pan $\left(\mathrm{mm} \mathrm{d}^{-1}\right)$.

Kpan = pan evaporation coefficient.

Monthly mean weather data for a 16-year (January 1997 - December 2013) were applied in this study. The averages of maximum and minimum air temperature, mean relative humidity, wind speed and class A pan evaporation are shown in Fig(1).

The crop water requirements (ETc) were estimated using the crop coefficient according to equation (2).

$$
E T c=E T o \times K c
$$

Where:

$$
\begin{aligned}
& \text { ETc }=\text { crop water requirements }\left(\mathrm{mm} \mathrm{d}^{-1}\right) . \\
& K c \quad=\text { crop coefficient. }
\end{aligned}
$$

Lengths of the different crop growth stages were 20, 30, 40, and 20 days for initial, crop development, mid-season and late season stages, respectively. The crop coefficients $(\mathrm{Kc})$ of initial, mid and end stages were $0.40,1.15$ and 0.35 respectively according to Allen et al. (1998). The amount of irrigation water applied (IWA) to each treatment was determined by using the equation (3):

$$
\mathrm{IWA}=\frac{\mathrm{A} \times \mathrm{ETc} \times \mathrm{Ii} \times \mathrm{Kr}}{\mathrm{Ea} \times 1000}+\mathrm{LR}
$$

Where:

IWA $=$ irrigation water applied $\left(\mathrm{m}^{3}\right)$.

A $=$ plot area $\left(\mathrm{m}^{2}\right)$.

ETc $=$ crop water requirements $\left(\mathrm{mm} \mathrm{d}^{-1}\right)$.

$\mathrm{I}_{\mathrm{i}} \quad=$ irrigation intervals (d).

$\mathrm{Kr}=$ coverage coefficient $\left(\mathrm{Kr}=\left(0.10+\mathrm{G}_{\mathrm{C}}\right) \leq 1\right)$

$\mathrm{Gc}=$ ground cover. 
$\mathrm{Ea}=$ application efficiency $(\%)(\mathrm{Ea}=85 \%)$.

$\mathrm{LR}=$ leaching requirements $\left(\mathrm{m}^{3}\right)$.
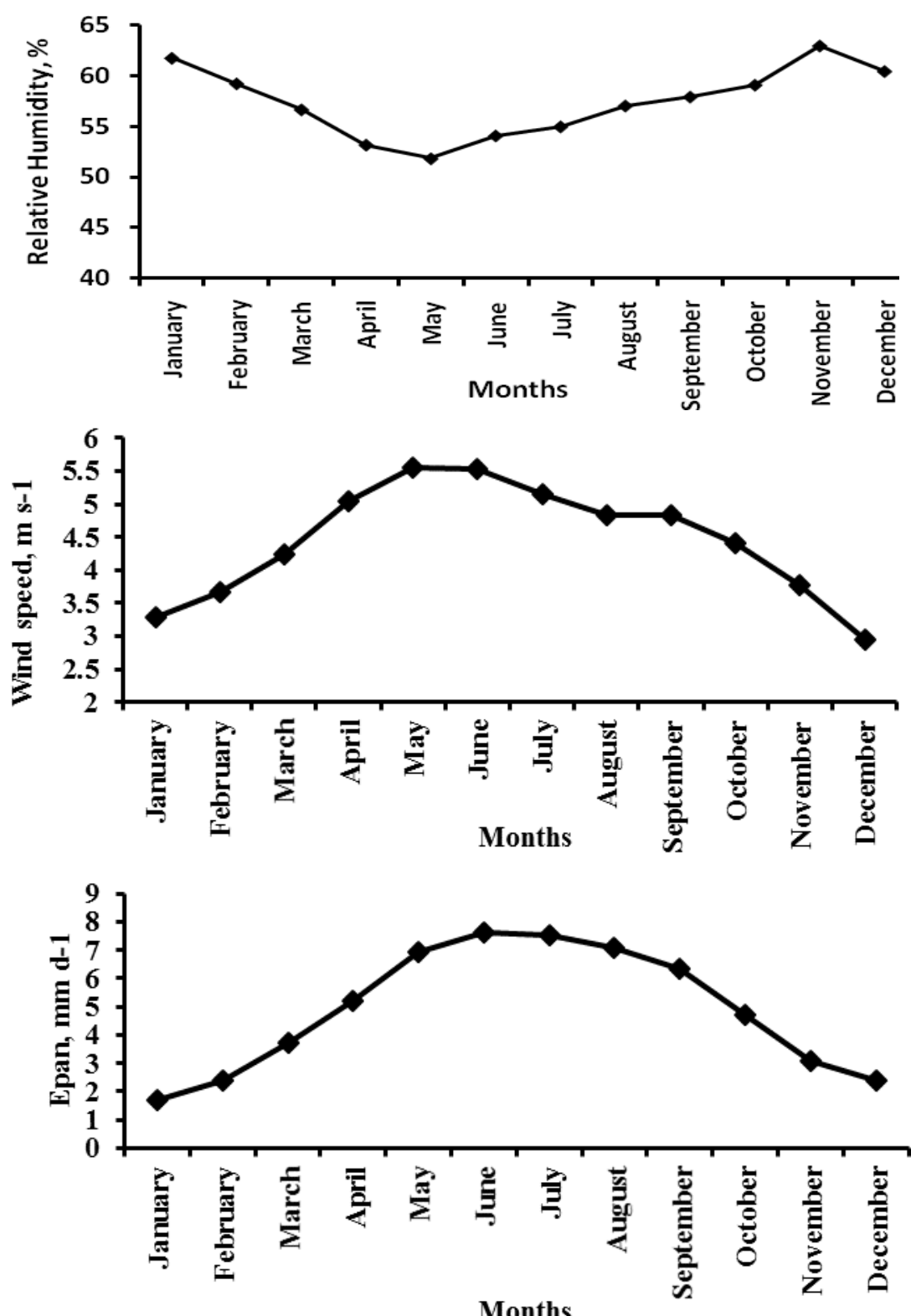

Fig.(1): The averages of maximum and minimum air temperature, mean relative humidity, wind speed and class A pan evaporation. 
The amounts of irrigation water applied were 1356, 1153 and $949 \mathrm{~m}^{3}$ fad $^{-1}$ for $\mathrm{I}_{100 \%}, \mathrm{I}_{85 \%}$ and $\mathrm{I}_{70 \%}$, respectively. Irrigation treatments were started after full plant emergence at which each treatment was irrigated according to prescribed irrigation scheduling treatments.

Seeds of bean (Nebraska) were hand planted (15 September 2014 and 14 September 2015) in drills $100 \mathrm{~cm}$ apart and $15 \mathrm{~cm}$ within hills. Plants were thinned to secure one plant per hill three weeks after planting. All other cultural practices were carried out as recommended for bean crop in both seasons.

After 45 days from sowing, random sample of three plants unit were taken from each experimental. Plant height $(\mathrm{cm})$, number of leaves plant ${ }^{1}$ and number of pods plant ${ }^{-1}$ were measured.

At harvest, random sample of five plants were taken from each experimental unit the 100-seed weight (g) and seed yields were measured per each experimental unit then transferred to seed yield $\mathrm{kg} \mathrm{fed}^{-1}$.

\subsection{Water use efficiency (WUE):}

Water use efficiency values as $\mathrm{kg}$ seeds $\mathrm{m}^{-3}$ of irrigation water applied were calculated for each treatment after harvest using equation (4) according to (Jensen, 1983).

$$
W U E=\frac{\text { seeds yield }\left(\mathrm{kg} \mathrm{fed}^{-1}\right)}{\text { irrigation water applied }\left(\mathrm{m}^{3} \mathrm{fed}^{-1}\right)}
$$

\subsection{Yield response factor $(\mathrm{Ky})$ :}

Yield response factor (Ky) was calculated by equation (5) according Stewart et al. (1977) as follows:

$$
\left(1-\frac{Y_{a}}{Y_{m}}\right)=k_{y}\left(1-\frac{E T_{a}}{E T_{m}}\right) \ldots \ldots \ldots \ldots
$$

Where:

$$
\begin{array}{ll}
Y_{a} & =\text { actual yield }\left(\mathrm{kg} \mathrm{fed}^{-1}\right), \\
Y_{m} & =\text { maximum yield }\left(\mathrm{kg} \mathrm{fed}^{-1}\right), \\
E T_{a} & =\text { actual crop evapotranspiration }(\mathrm{mm}), \\
E T_{m} & =\text { maximum crop evapotranspiration }(\mathrm{mm}) .
\end{array}
$$




\subsection{Statistical analysis.}

Appropriate analysis of variance was performed on results of each experiment. Comparisons among means of the treatments were performed using the Revised Least Significant Difference procedure at $P=0.05$ level as illustrated by Snedecor and Cochran (1980).

\section{RESULTS AND DISCUSSION}

\subsection{Bean yield and yield components:}

Data presented in Tables (4 and 5) showed that all the studied parameters were significantly affected by irrigation treatments and thickness of rice straw mulch layer.

It is clear that average seed yields of bean crop were increased with increasing the amount of irrigation water applied. Data in Table (5) demonstrated that, the greatest value of bean yield (902.4and $909.6 \mathrm{~kg}$ fed $^{-1}$ ) was obtained under $\left(\mathrm{I}_{100 \%}\right)$ in the first and second season, respectively, while the lowest ones (698.1 and $692.5 \mathrm{kgfed}^{-1}$ ) were obtained from $\left(\mathrm{I}_{70 \%}\right)$ in the first and second seasons, respectively. Similar were obtained by Abd El-Wahed and Ali (2013) on corn, trends Abd ElMageed, et al, (2016), on squash. These results may be due to the sufficient available water in the root zone under $\left(\mathrm{I}_{100 \%}\right)$ which may led to increases in both water and nutrients absorption and consequently increases in the metabolic mechanisms that finally resulted in the increase in the number of pods plant ${ }^{-1}$ and the 100- dry seed weight $(\mathrm{g})$. As an average, the maximum value of number of pods plant $^{-1}$ and the 100dry seed weight (11.55 and $73.8 \mathrm{~g}$ ) were obtained under $\left(\mathrm{I}_{100 \%}\right)$, while the lowest ones (9.74 and $60.25 \mathrm{~g}$ ) were obtained from $\left(\mathrm{I}_{70 \%}\right)$, respectively, Tables (4 and 5).

Data given in Table (6) showed that, decreasing irrigation water by 15 and $30 \%$ from IWA for treatments $\mathrm{I}_{85 \%}$ and $\mathrm{I}_{70 \%}$ caused reductions in yield by 7.0 and $22.6 \%$ in the first season and 8.1 and $23.9 \%$, in the second season, then the $\mathrm{I}_{100 \%}$ treatment. This may be due to the reduction in available soil moisture, which consequently resulted in reducing absorption of both water and nutrient elements. In arid and semi-arid regions very often moisture stress is the limiting factor for crop growth 
and yield production, however, there is a strong interaction between water supply and plant nutrient availability (Tahir, 1983).

Table (4): Effect of irrigation treatments, thickness of mulch layer and their interaction on plant height $(\mathrm{cm})$, number of leaves plant ${ }^{-1}$ and number of pods plant ${ }^{-1}$.

\begin{tabular}{|c|c|c|c|c|c|c|c|}
\hline \multirow{2}{*}{$\begin{array}{l}\text { Irrigation } \\
\text { treatments } \\
\text { (I) }\end{array}$} & \multirow[t]{2}{*}{ TML } & \multicolumn{2}{|c|}{$\begin{array}{c}\text { Plant height } \\
(\mathrm{m})\end{array}$} & \multicolumn{2}{|c|}{$\begin{array}{c}\text { No. of leaves plant } \\
1\end{array}$} & \multicolumn{2}{|c|}{ No. of pods plant ${ }^{-1}$} \\
\hline & & 2014 & 2015 & 2014 & 2015 & 2014 & 2015 \\
\hline \multirow{5}{*}{$\mathrm{I}_{100 \%}$} & 0 & 26.4 & 23.1 & 4.8 & 4.3 & 10.2 & 9.9 \\
\hline & 3 & 26.2 & 25.1 & 5.2 & 5.1 & 11.4 & 10.8 \\
\hline & 6 & 28.2 & 27.1 & 5.6 & 5.6 & 11.9 & 11.9 \\
\hline & 9 & 29.4 & 27.2 & 6.4 & 6.4 & 13.3 & 13 \\
\hline & Average & 27.6 & 25.6 & 5.5 & 5.3 & 11.7 & 11.4 \\
\hline \multirow{5}{*}{$\mathrm{I}_{85 \%}$} & 0 & 23.9 & 21.3 & 4.6 & 4.3 & 9.2 & 9.1 \\
\hline & 3 & 25.8 & 23 & 5.3 & 4.8 & 10 & 10 \\
\hline & 6 & 26.6 & 24.8 & 4.3 & 5.6 & 10.7 & 10.7 \\
\hline & 9 & 27.4 & 25.8 & 5.7 & 6.1 & 12.3 & 12.1 \\
\hline & Average & 25.9 & 23.7 & 5 & 5.2 & 10.6 & 10.5 \\
\hline \multirow{5}{*}{$\mathrm{I}_{70 \%}$} & 0 & 25 & 18 & 4.1 & 4.1 & 8.1 & 8.4 \\
\hline & 3 & 24.7 & 19.7 & 4.7 & 4.8 & 8.8 & 9.8 \\
\hline & 6 & 25 & 21 & 4.9 & 5 & 9.4 & 10.1 \\
\hline & 9 & 25.9 & 23.2 & 5.3 & 5.6 & 11.6 & 11.7 \\
\hline & Average & 25.2 & 20.5 & 4.7 & 4.9 & 9.5 & 10 \\
\hline \multicolumn{2}{|c|}{ General Average } & 26.2 & 23.3 & 5.1 & 5.1 & 10.6 & 10.6 \\
\hline \multicolumn{2}{|c|}{0} & 25.10 & 20.80 & 4.50 & 4.23 & 9.17 & 9.13 \\
\hline \multicolumn{2}{|c|}{3} & 25.57 & 22.60 & 5.07 & 4.90 & 10.07 & 10.20 \\
\hline \multicolumn{2}{|c|}{6} & 26.60 & 24.30 & 4.93 & 5.40 & 10.67 & 10.90 \\
\hline \multicolumn{2}{|c|}{9} & 27.57 & 25.40 & 5.80 & 6.03 & 12.40 & 12.27 \\
\hline \multicolumn{2}{|c|}{$\operatorname{LSD}_{0.05}$ for I } & 1.4 & 1.1 & 0.3 & 0.3 & 0.5 & 0.4 \\
\hline \multicolumn{2}{|c|}{$\mathrm{LSD}_{0.05}$ for TML } & 1.6 & 1.3 & 0.3 & 0.3 & 0.6 & 0.5 \\
\hline \multicolumn{2}{|c|}{$\mathrm{LSD}_{0.05}$ for $\mathrm{I} \times \mathrm{TML}$} & n.s. & n.s. & n.s. & n.s. & n.s. & n.s. \\
\hline
\end{tabular}


Table (5): Effect of irrigation treatments, thickness of mulch layer and their interaction on 100- dry seed weight (g), seed yields $\left(\mathrm{kg} \mathrm{fed}^{-1}\right)$ and water use efficiency (WUE).

\begin{tabular}{|c|c|c|c|c|c|c|c|}
\hline \multirow{2}{*}{$\begin{array}{l}\text { Irrigation } \\
\text { treatments }\end{array}$} & \multirow[t]{2}{*}{ TML } & \multicolumn{2}{|c|}{$\begin{array}{c}\text { 100- dry seed } \\
\text { weight }(\mathrm{g})\end{array}$} & \multicolumn{2}{|c|}{$\begin{array}{l}\text { seed yields } \\
\left(\mathrm{kg} \mathrm{fed}^{-1}\right)\end{array}$} & \multicolumn{2}{|c|}{$\begin{array}{lll}\text { WUE } & (\mathrm{kg} \\
& \left.\mathrm{m}^{-1}\right) & \\
\end{array}$} \\
\hline & & 2014 & 2015 & 2014 & 2015 & 2014 & 2015 \\
\hline \multirow{5}{*}{$\mathrm{I}_{100 \%}$} & 0 & 66.3 & 67.2 & 774.1 & 773.0 & 0.57 & 0.57 \\
\hline & 3 & 71.3 & 72.5 & 829.5 & 824.0 & 0.61 & 0.61 \\
\hline & 6 & 76.5 & 76.6 & 963.6 & 973.8 & 0.71 & 0.72 \\
\hline & 9 & 79.4 & 80.3 & 1042.4 & 1067.6 & 0.77 & 0.79 \\
\hline & Average & 73.4 & 74.2 & 902.4 & 909.6 & 0.67 & 0.67 \\
\hline \multirow{5}{*}{$\mathrm{I}_{85 \%}$} & 0 & 60.2 & 61.7 & 711 & 691.3 & 0.62 & 0.6 \\
\hline & 3 & 64.4 & 65.2 & 742.3 & 759.4 & 0.64 & 0.66 \\
\hline & 6 & 72.3 & 73.4 & 896.7 & 879.2 & 0.78 & 0.76 \\
\hline & 9 & 75.4 & 76.1 & 1008.8 & 1015.6 & 0.87 & 0.88 \\
\hline & Average & 68.1 & 69.1 & 839.7 & 836.4 & 0.73 & 0.73 \\
\hline \multirow{5}{*}{$\mathrm{I}_{70 \%}$} & 0 & 55.0 & 55.0 & 578.4 & 569.4 & 0.61 & 0.6 \\
\hline & 3 & 59.4 & 60.6 & 639.1 & 619.6 & 0.67 & 0.65 \\
\hline & 6 & 61.7 & 62.4 & 733.3 & 745.7 & 0.77 & 0.79 \\
\hline & 9 & 63.1 & 64.6 & 841.6 & 835.3 & 0.89 & 0.88 \\
\hline & Average & 59.8 & 60.7 & 698.1 & 692.5 & 0.74 & 0.73 \\
\hline \multicolumn{2}{|c|}{ General Average } & 67.1 & 68.0 & 813.4 & 812.8 & 0.71 & 0.71 \\
\hline \multicolumn{2}{|c|}{0} & 60.5 & 61.3 & 687.83 & 677.9 & 0.60 & 0.59 \\
\hline \multicolumn{2}{|c|}{3} & 65.0 & 66.1 & 737.0 & 734.3 & 0.64 & 0.64 \\
\hline \multicolumn{2}{|c|}{6} & 70.2 & 70.8 & 864.5 & 866.2 & 0.75 & 0.76 \\
\hline \multicolumn{2}{|c|}{9} & 72.6 & 73.7 & 964.3 & 972.8 & 0.84 & 0.85 \\
\hline \multicolumn{2}{|c|}{$\operatorname{LSD}_{0.05}$ for I } & 1.7 & 1.5 & 24 & 29 & 0.02 & 0.03 \\
\hline \multicolumn{2}{|c|}{$\mathrm{LSD}_{0.05}$ for TML } & 2.0 & 1.7 & 27 & 34 & 0.02 & 0.03 \\
\hline \multicolumn{2}{|c|}{$\mathrm{LSD}_{0.05}$ for $\mathrm{I} \times \mathrm{TML}$} & n.s. & n.s. & n.s. & n.s. & n.s. & n.s. \\
\hline
\end{tabular}

Data presented in Tables (4 and 5) showed that, all the studied parameter were significantly affected by the thickness of rice straw mulch layer (TML). The average common bean yield value of treatment (TML 9 ) was increased by $11.5,30.8$ and $40.2 \%$ than those of $\left(\mathrm{TML}_{6,3}\right.$ and 0 ,) 
respectively, in the first season. Corresponding values of the second season were $12.3,32.5$ and $43.5 \%$. These results resembled the finding of Abd El-Wahed and Ali (2013).

Table (6): Effect of irrigation treatments and rice straw mulching types on water saving (WS), common bean yield (Y) and yield reduction (YR) for the two growing seasons 2014 and 2015.

\begin{tabular}{|c|c|c|c|c|c|c|c|c|}
\hline \multirow{3}{*}{ Irrigation treatments } & \multirow[b]{3}{*}{ IWA $\mathrm{m}^{3} \mathrm{fed}^{-1}$} & \multirow{3}{*}{$\begin{array}{c}\text { WS } \\
\%\end{array}$} & \multicolumn{2}{|c|}{2014} & \multicolumn{2}{|c|}{2015} & \multicolumn{2}{|c|}{ Average } \\
\hline & & & Y & YR & $\mathrm{Y}$ & YR & Y & YR \\
\hline & & & $\mathrm{kg} \mathrm{fed}^{-1}$ & $\%$ & $\mathrm{~kg} \mathrm{fed}^{-1}$ & $\%$ & $\mathrm{~kg} \mathrm{fed}^{-1}$ & $\%$ \\
\hline $\mathrm{I}_{100 \%}$ & 1356.4 & 0 & 902.4 & 0 & 909.6 & 0 & 958.8 & 0 \\
\hline $\mathrm{I}_{85 \%}$ & 1152.9 & 15 & 839.7 & 7.0 & 836.4 & 8.1 & 878.0 & 8.4 \\
\hline $\mathrm{I}_{70 \%}$ & 949.5 & 30 & 698.1 & 22.6 & 692.5 & 23.9 & 733.4 & 23.5 \\
\hline
\end{tabular}

The increase in yield because of the use of rice straw mulch treatments compared with no mulch can be attributed to reduction in water evaporation from soil, conserving more available water decreasing salt in soil surface that may consequently increases crop yield. Also, the organic mulch could add nutrients to soil when decomposed by microbes, and this helps in carbon sequestration (Chattopadhyaya and Mukherjee, 1990). The addition, of organic manure, improve soil physical properties as well as increases soil water holding capacity which give rise to good aeration and drainage that encourage better root growth and nutrient absorption (Abou El-Magd et al., 2008).

Data obtained showed that Plant height, number of leaves plant ${ }^{-1}$, number of pods plant ${ }^{-1}, 100$ - dry seed weight, seed yields and WUE were not significantly affected by the interaction between irrigation treatments and thickness of mulch layer. The highest bean yields (1042.4 and $1067.6 \mathrm{~kg}$ $\mathrm{fed}^{-1}$ ) were recorded for plants irrigated with the highest level of AIW $\left(\mathrm{I}_{100 \%}\right)$ and applied TML. In contrast, the lowest bean yield (578.4and $569.4 \mathrm{~kg} \mathrm{fed}^{-1}$ ) was obtained from plants irrigated with the lowest level of AIW $\left(\mathrm{I}_{70 \%}\right)$ under no mulch $\mathrm{TML}_{0}$ in both seasons, respectively Table (5). 
As shown in (Table 5), the average bean yield for $\mathrm{I}_{85} \%$ under TML9 (1008.8 and $1015.6 \mathrm{~kg} \mathrm{fed}^{-1}$ ) in both seasons resulted in the production of to that of nearly identical value to that of treatment $\mathrm{I}_{100 \%}$ under TML9 (1042.4 and $1067.6 \mathrm{~kg} \mathrm{fed}^{-1}$ ) in both seasons. Under limited irrigation water, it in clean that applying the $\left(\mathrm{I}_{85}\right)$ and $\mathrm{TML}_{9}$ could save $15 \%$ of the applied irrigation water with no decrease the same common bean yield.

\subsection{Water use efficiency (WUE)}

Data give in Table (5) showed that, WUE was significantly affected by irrigation treatments and thickness of mulch layer treatments.

The greatest value of WUE $\left(0.74\right.$ and $\left.0.73 \mathrm{~kg} \mathrm{~m}^{-3}\right)$ was obtained under $\mathrm{I}_{70 \%}$ compared to under $\mathrm{I}_{100 \%},\left(0.67 \mathrm{~kg} \mathrm{~m}^{-3}\right)$ in the two seasons, respectively. These results are in agreement with those of (Abd ElMageed, et al., 2016) on squash crop.

Regarding thickness of rice straw mulch layer treatments, Table (5) showed that, WUE was significantly affected by the thickness of mulch layer (TML). The average WUE values of TML9 were increased by 40.6 , 31.8 and $11.9 \%$ than those of TML0, TML3 and TML6, respectively, in 2014 season. Corresponding values in 2015 season were 44.1, 32.8 and $12.3 \%$, respectively. Similar trend was reported by Abd El-Wahed and Ali, 2013 on corn crop. Data in Table (5) also indicated that WUE was not significantly affected by the interactions between irrigation treatments and thickness of mulch layer treatments.

\subsection{Yield response factor $(\mathrm{Ky})$ :}

Table (7) and figure (2) presents, the relationship between the reduction in relative yield $[1-(\mathrm{Ya} / \mathrm{Ym})]$ and the effect treatments the reduction in irrigation water applied [1- (ETa/ETm)] under. According to Table (7), it is clear from data that the decrease in common bean yield was less than the decrease in water use, since all values of the yield response values $\left(\mathrm{K}_{\mathrm{y}}\right)$ were less than 1.This result means that, common beans in tolerant to water, Under all treatments, Ky values for $\mathrm{I}_{70 \%}$ were always greater than those of $\mathrm{I}_{85 \%}$ and $\mathrm{I}_{100 \%}$. These results are in agreement with those of 
Comlekcioglu et al. (2011) who reported that ky value differ due to the deficit irrigation which affects yield and yield component

Data of the present work showed a linear relationship was found between the reductions in relative yield and the reduction in irrigation water applied is shown in (Fig 2). They reported that the Ky usually indicates a linear relationship of the relative reduction in water that was consumed with a relative reduction in yield. The average crop response factor for the different treatments throughout beans growth was 0.73 and 0.72 for the two seasons 2014 and 2015 seasons, respectively, (Fig 2). This result indicated that the reduction in crop productivity is proportionally less than the relative ET deficit in both cases. Results estimated by equation (5) or by linear regression Fig (2), have indicated that common beans crop is tolerant to water deficit.

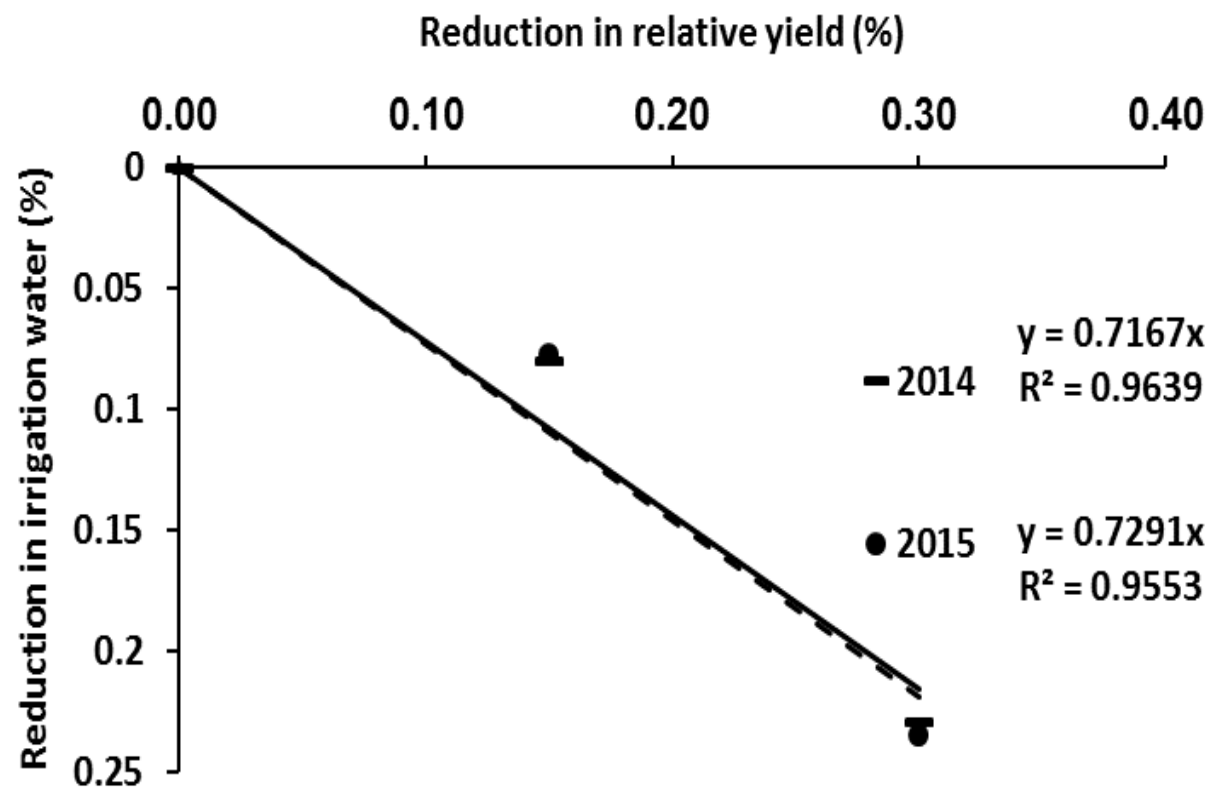

Fig. (2): Relationship between the reduction in irrigation water and reduction in relative yield for beans crop under drip irrigation. 
Table (7): The yield response factor of bean crop under irrigation water applied and thickness of mulch layer.

\begin{tabular}{|c|c|c|c|c|c|c|c|}
\hline Tre. & AIW & GY & Ya/Ym & ETa/ETm & $1-$ Ya/Ym & 1 - ETa/ETm & Ky \\
\hline \multicolumn{7}{|c|}{ TML0 } \\
\hline$I_{100}$ & 1356.4 & 773.6 & 1 & 1 & 0 & 0 & 0 \\
\hline$I_{85}$ & 1152.9 & 701.1 & 0.91 & 0.85 & 0.09 & 0.15 & 0.62 \\
\hline$I_{70}$ & 949.5 & 573.9 & 0.74 & 0.70 & 0.26 & 0.30 & 0.86 \\
\hline \multicolumn{7}{|c|}{ TML3 } \\
\hline$I_{100}$ & 1356.4 & 826.7 & 1 & 1 & 0 & 0 & 0 \\
\hline$I_{85}$ & 1152.9 & 750.8 & 0.91 & 0.85 & 0.09 & 0.15 & 0.61 \\
\hline$I_{70}$ & 949.5 & 629.3 & 0.76 & 0.70 & 0.24 & 0.30 & 0.80 \\
\hline \multicolumn{7}{|c|}{ TML6 } \\
\hline$I_{100}$ & 1356.4 & 968.7 & 1 & 1 & 0 & 0 & 0 \\
\hline$I_{85}$ & 1152.9 & 887.9 & 0.92 & 0.85 & 0.08 & 0.15 & 0.56 \\
\hline$I_{70}$ & 949.5 & 739.5 & 0.76 & 0.70 & 0.24 & 0.30 & 0.79 \\
\hline \multicolumn{7}{|c|}{ TML9 } \\
\hline$I_{100}$ & 1356.4 & 1055.0 & 1 & 1 & 0 & 0 & 0 \\
\hline$I_{85}$ & 1152.9 & 1012.2 & 0.96 & 0.85 & 0.04 & 0.15 & 0.27 \\
\hline$I_{70}$ & 949.5 & 838.4 & 0.79 & 0.70 & 0.21 & 0.30 & 0.68 \\
\hline
\end{tabular}

\section{CONCLUSIONS}

The effects of deficit irrigation and thickness of mulch layer on yield, yield components and water use efficiency was studied in two field experiments conducted in the growth seasons (2014 and 2015).

The greatest values of bean yield (902.4and $909.6 \mathrm{~kg} \mathrm{fed}^{-1}$ ) were obtained under $\left(\mathrm{I}_{100 \%}\right)$ in the first and second season, respectively, while the lowest ones (698.1 and $692.5 \mathrm{kgfed}^{-1}$ ) were obtained with treatment $\left(\mathrm{I}_{70 \%}\right)$ in the first and second season, respectively. The average bean yield value of $\mathrm{TML}_{9}$ was increased by $11.5,30.8$ and $40.2 \%$ than those of $\mathrm{TML}_{6,3}$ and 0 , respectively, in the first season. Corresponding values in the second season were $12.3,32.5$ and $43.5 \%$

The greatest values of WUE $\left(0.74\right.$ and $\left.0.73 \mathrm{~kg} \mathrm{~m}^{-3}\right)$ were obtained under $\mathrm{I}_{70 \%}$ compared to $\left(0.67 \mathrm{~kg} \mathrm{~m}^{-3}\right)$ under $\mathrm{I}_{100 \%}$, in the two studied seasons, respectively. 
It could be considered as a suitable under environmental conditions of study area and similar areas, the treatment $\left(\mathrm{I}_{100} \times \mathrm{TML}_{9}\right)$ is the most suitable for producing high bean crop. Under limited irrigation water, application of $\left(\mathrm{I}_{85} \times \mathrm{TML}_{9}\right)$ treatment was found to be favorable to save $15 \%$ of the applied irrigation water, with no reduction in common bean crop.

\section{REFERENCES}

Abd El-Mageed, T. A., Semida, W. M. and Abd El-Wahed, M. H., 2016.Effect of mulching on plant water status, soil salinity and yield of squash under summer-fall deficit irrigation in salt affected soil. Agric. Water Manage.173:1-12.

Abd El-Wahed, M.H. and Ali, E.A. 2013.Effect of irrigation systems, amounts of irrigation water and mulching on corn yield, water use efficiency and net profit. Agric. Water Manage.120:64-71.

Abou El-Magd, M.M., Zaki, M.F. and Abou-Hussein, S.D., 2008.Effect of organic manure and different levels of saline irrigation water on growth, green yield and chemical content of sweet fennel. Aust. J. Bas. App. Sci, 2, pp.1-90.

Allen, R.G., Pereira, L.S., Raes, D., Smith, M., 1998.Crop evapotranspiration. In Guidelines for Computing Crop Water Requirements. FAO, Rome.

Chattopadhyaya, N. and Mukherjee, D., 1990. Effect of mulching on the changes in the microbial population in soil and nodulation of lentil (Lens culinaris Medik CV B-77).Environment and Ecology, 8(1B), pp.435-437.

Simsek, M., and N. Comlekcioglu. "Effects of different irrigation regimes and nitrogen levels on yield and quality of melon (Cucumis melo L.)." African Journal of Biotechnology 10.49 (2011): 10009-10018.

Dabney, S.M., Delgado, J.A. and Reeves, D.W., 2001. Using winter cover crops to improve soil and water quality. Communications in Soil Science and Plant Analysis, 32(7-8), pp.1221-1250. 
Doorenbos, J. and W.O. Pruitt. 1992. Crop water requirements. FAO Irrigation and Drainage.Paper, No. 24, FAO, Rome, 144 pp.

Egypt in Figures, 2015. Ministry of Water Resources \& Irrigation.

El-Hendawy, S.E., Hokam, E.M. and Schmidhalter, U., 2008. Drip irrigation effects of water quality and drip rate on soil salt distribution in Earth, 29, 1035-1042.

Falagán, N., Artés, F., Artés-Hernández, F., Gómez, P.A., Pérez-Pastor, A. and Aguayo, E., 2015. Comparative study on postharvest performance of nectarines grown under regulated deficit irrigation. Postharvest Biology and Technology, 110, pp.24-32.

Melgarejo, Pablo, et al. "Chemical, functional and quality properties of Japanese plum (Prunus salicina Lindl.) as affected by mulching." Scientia Horticulture 134 (2012): 114-120.

Hartkamp, A.D., White, J.W., Rossing, W.A.H., Van Ittersum, M.K., Bakker, E.J. and Rabbinge, R., 2004. Regional application of a cropping systems simulation model: crop residue retention in maize production systems of Jalisco, Mexico. Agricultural systems, 82(2), pp.117-138.

Jensen, M.E., 1983. Design and operation of farm irrigation systems. ASAE, Michigan, USA. pp. 827.

Kar, G. and Kumar, A., 2007. Effects of irrigation and straw mulch on water use and tuber yield of potato in eastern India. Agricultural Water Management, 94(1), pp.109-116.

Melgarejo, P., et al. "Estudio de la capacidad de enraizamiento de once clones de granado (Punica granatum L.), utilizando la técnica de acolchado del suelo." I Symposium Internacional sobre el granado. Orihuela (Alicante). 1998.

Nangare, D.D., Singh, Y., Kumar, P.S. and Minhas, P.S., 2016. Growth, fruit yield and quality of tomato (Lycopersicon esculentum Mill.) as affected by deficit irrigation regulated on phenological basis. Agricultural Water Management, 171, pp.73-79. 
Ramirez Builes, V.H., Porch, T.G., Harmsen, E.W., 2011. Genotypic differences inwater use efficiency of common bean under drought stress. Agron. J. 103 (4), 1206-1215.

Snedecor, C.W. and W.C. Cochran. 1980. Statistical Methods. 7th Ed. Iowa State Univ. Press, Ames, Iowa.

Stewart, A. L. Ware, J. E., Davies, A. R., (1977). The measurement and meaning of patient satisfaction: a review of the literature.

Trenor, I., Zaragoza, S., Cortés de Lacour, P. and Clarí, A., 1998.Cultivo de variedades marisol y oronules bajo cubierta de malla. Rev. Comunitat Valenciana Agraria, 11, pp.3-11.

Wei, M.I.N., GUO, H.J., ZHANG, W., ZHOU, G.W., Jun, Y.E. and HOU, Z.A., 2016. Irrigation water salinity and $\mathrm{N}$ fertilization: Effects on ammonia oxidizer abundance, enzyme activity and cotton growth in a drip irrigated cotton field. Journal of Integrative Agriculture, 15(5), pp.1121-1131.

\title{
الملخص العربي \\ تقييم تأثير الري المتناقص بالتنقيط وعمق طبقات التغطية بقش الأرز على التى الفاصوليا وكفاءة استخدام المياه
}

\begin{abstract}
محمد حسن عبد الواحد' جمعة عبد ربه بكير' محمود محمد على' و فاطمة عادل عبد الفتاح'
اجريت الدراسة الحالية بهدف تقدير نأثير الري المتناقص و التغطية بأستخدام قش الأرز بأعماق

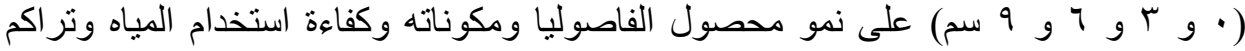

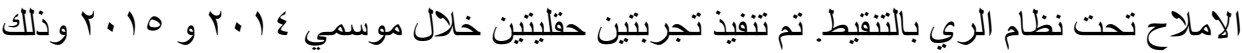

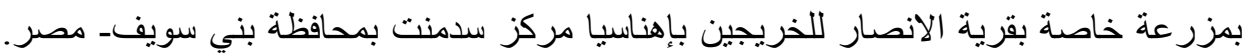

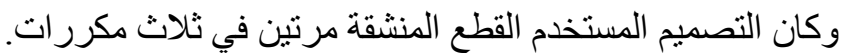

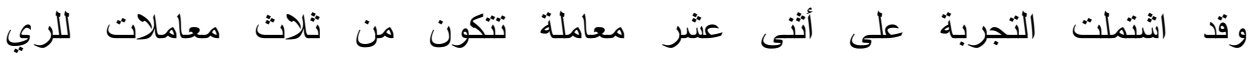

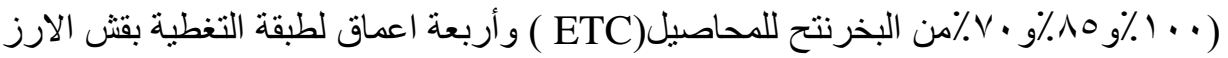

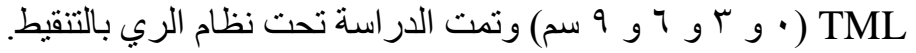


وأوضحت النتائج أن تأثير الري المتناقص وعمق طبقة التغطية على المحصول كان معنويا.

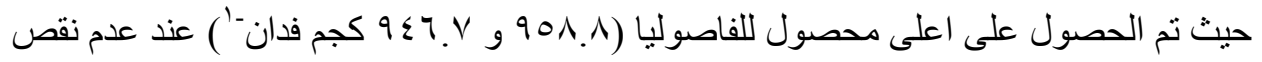

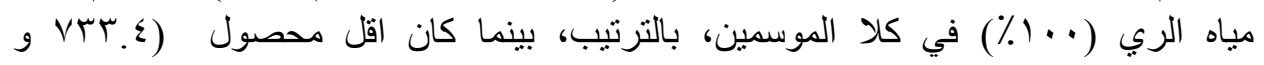

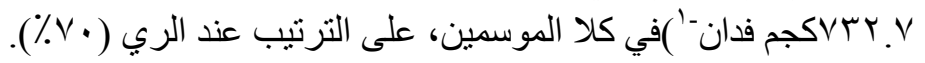

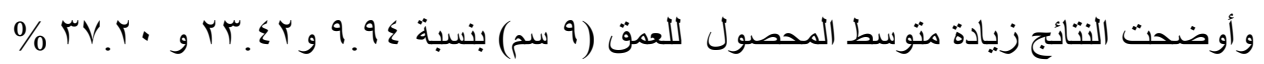

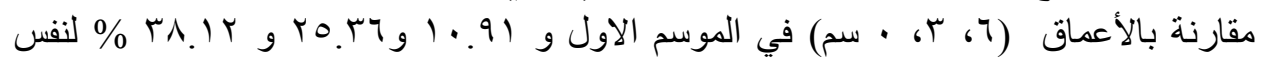
المعاملات في الموسم الثناني.

ويعتبر انسب معاملة تحت ظروف منطقة الدراسة هي الري عند نسبة ( . . (\%) من قيمه البخر

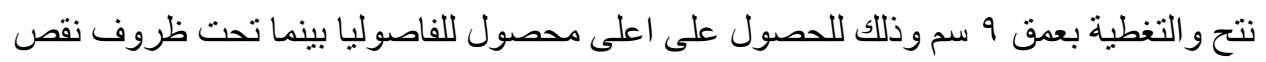

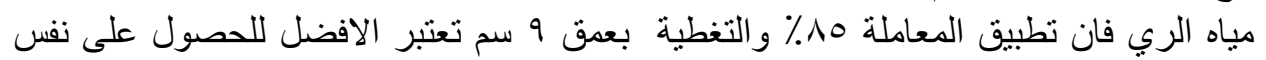

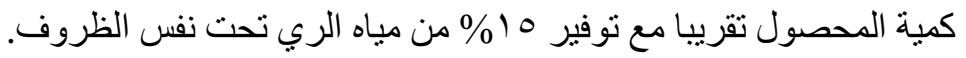

